\title{
Lectotypification of the names of three moss species described by Hedwig
}

\begin{abstract}
Alicia Ederra
Departamento de Botánica, Facultad de Ciencias, Universidad de Navarra. E-31008 Pamplona, Spain. aederra@unav.es (author for correspondence)
\end{abstract}

As a part of a study for the project "Flora Briofítica Ibérica" three names, Bartramia halleriana Hedw., Bartramia pomiformis Hedw. and Anictangium aquaticum Hedw. [三 Cinclidotus aquaticus (Hedw.) Bruch \& Schimp.], described by Johannes Hedwig, are lectotypified.

KEYWORDS: Bryophyta, lectotypification, Bartramia, Cinclidotus, Hedwig.

Lectotypification of the 369 names found in Hedwig's Species Muscorum (1801), the starting point for the nomenclature of mosses except Sphagnum, is necessary for nomenclatural stability (Florschütz, 2002). Hedenäs \& Geissler (1999) have lectotypified many pleurocarpous mosses and Koponen (1979), Pursell (1986), Geissler \& Frahm (1995) and Geissler (2000) are significant papers on the lectotypification of names of acrocarpous mosses. However, currently fewer than onehalf of the names have been lectotypified ( $\mathrm{w}^{3}$.ville-ge.ch/ cjb, 2005).

While studying the genera Bartramia Hedw. and Cinclidotus P. Beauv. for the project "Flora Briofítica Ibérica", I had the opportunity to study the types of $B$. halleriana Hedw., B. pomiformis Hedw. and Anictangium aquaticum Hedw. [ $\equiv$ Cinclidotus aquaticus (Hedw.) Bruch \& Schimp.] deposited in the Hedwig-Schwägrichen Herbarium in G. Following the advice of M. Price, Curator of Bryophytes in G, these three names are herein lectotypified. The specimens in Hedwig-Schwägrichen Herbarium are considered "oligotypes" (Huhtinen, 1994), so they have been studied especially carefully.

Bartramia halleriana Hedw., Sp. Musc. Frond. 164. 1801. - Lectotype (designated here): "Bartramia halleriana Hedw. St. Crypt. Vol. II. p. iii t. $40 /$ Bryum laterale S.V. / * planta delineata" - the third specimen from the left on the sheet-(Herbarium Hedwig-Schwägrigen in G!).

There is one sheet of $B$. halleriana in the HedwigSchwägrichen herbarium, with the label in Hedwig's handwriting: "Bartramia halleriana Hedw. St. Crypt. Vol. II. p. iii t. 40 / Bryum laterale S.V. / *. planta delineata". Four specimens are arranged in one row, glued on the upper part of the sheet. The first and the third specimens from the left are well-developed plants, the second (with an * at its base) and the fourth are isolated stems. All bear sporophytes but in various states of preserva- tion; the first has two or three rather deteriorated capsules concealed by leaves, lacking opercula but with a few small fragments of peristome teeth; the second has one capsule with a complete peristome; the third has two capsules, one with the operculum, the other lacking an operculum, but with a very well-preserved peristome; the fourth has one capsule with a well-preserved peristome. All specimens correspond to the current understanding of the species.

The protologue of the species includes: "Hedw. st. cr. p. III t. 40. ... in Saxonia, Hercynia, monte pinifero Franconiae, in alpibus Judenburgensibus Styriae, Carinthia, nec non in Helvetia”. In Hedwig (1785-1797), Table XL of vol. II, there are twelve drawings that represent different features of $B$. halleriana. Among these, Fig. 1 was most likely based on the first specimen to the left on the herbarium sheet; Fig. $1 *$ represents an isolated stem and Fig. 3 is the same stem at higher magnification, and both correspond to the second specimen on the herbarium sheet, i.e., the one designated with an *, the "planta delineata". Since the same number was used by Hedwig, it is reasonable to assume that specimens $1 *$ and 3 were separated from specimen 1. Fig. 2 in Table XL represents another isolated stem, this one bifid, which closely resembles the fourth specimen on the sheet. There are no data on the label about localities that correspond with those given in the protologue. Since there is no indication on the label about differences among the specimens, one can assume Hedwig studied all four specimens. Therefore, because the third specimen from the left on the sheet is the best developed and preserved, it is herein designated lectotype.

Bartramia pomiformis Hedw., Sp. Musc. Frond. 164. 1801. - Lectotype (designated here): "Bartramia pomiformis Hedw. St. Crypt. Vol. II. p. / Bryum pomiforme S.V."- first specimen to the left in the upper row- (Herbarium Hedwig-Schwägrichen in G!). 
The only sheet of $B$. pomiformis in the HedwigSchwägrichen herbarium contains ten specimens arranged in two rows. The upper row has seven plants, the first from the right is marked " $\alpha$ " and the second " $\beta$ ", both lack sporophytes; four specimens from the left bear mature sporophytes and the fifth specimen from the left has several broken setae and a young capsule. The lower row, in the middle of the sheet, has three plants with mature sporophytes, all marked with the letter "b". There are also two small envelopes glued in the lower middle of the sheet, one has the word "Folia" and the other has "Perist.", both words in Hedwig's handwriting.

The label reads "Bartramia pomiformis Hedw. St. Crypt. Vol. II. p. / Bryum pomiforme S.V." (in Hedwig's hand) "b. exempla picta a Bocx" (in Schwägrichen's hand).

The seven plants in the upper row and the two envelopes must have been on the original Hedwig sheet. However, the three plants in the middle row must have been added by Schwägrichen because they are marked with "b", an often used practice (Geissler, 2000). Moreover, they are attached differently: Hedwig glued his plants from base to apex, including sporophytes, as are the seven plants in the upper row, but Schwägrichen glued plants only at the base, the upper parts and the sporophytes remaining free, as are the three plants in the lower row.

All these specimens represent B. pomiformis. However, the three to the right in the upper row, whose habit is clearly different, better represent var. crispa (Brid.) Bruch \& Schimp. (三B. crispa Brid., Muscol. Recent. 2(3): 131. 1803), which is considered to be an expression of shady and humid habitats and is synonymized with $B$. pomiformis ( $\mathrm{w}^{3}$.MOST, 2005; Crum \& Anderson, 1981; Smith, 2004; Fransén, 2004). Bridel (1803) related both taxa and hinted that B. crispa was only a variety of $B$. pomiformis ("Vix pro mera varietate habenda").

Two facts are noteworthy: first, the protologue in Hedwig (1801) contains no reference to any previous Hedwig's publication, but the label on the sheet in his herbarium states "St. Crypt. Vol. II. p.", although the reference is, evidently, incomplete; second, there is no information in Hedwig (1785-1797) about B. pomiformis, but there is on pages 45-46 and Table LVIII, Fig. 1-9 in Schwägrichen (1816). Although Hedwig did not include B. pomiformis in his "St. Crypt. Vol. II", the information on the label suggests that he intended to do so. Moreover, the two envelopes on the sheet indicate that he studied these specimens. Thus, disregarding the specimens added by Schwägrichen and the three specimens of var. crispa, the first specimen to the left in the upper row is herein selected as lectotype.
Anictangium aquaticum Hedw., Sp. musc. frond. 41. $1801 \equiv$ Cinclidotus aquaticus (Hedw.) Bruch \& Schimp., Bryol. eur. 3: 170. 1842. - Lectotype (designated here): "Anoectangium aquaticum Hedw. Stirp. III. t. / a. von Hedwig" (Herbarium HedwigSchwägrichen in G!).

There are six specimens on the one sheet of Anictangium aquaticum in the Hedwig-Schwägrichen herbarium; three are marked "a", two "b" and one "c". The sheet lacks a label; the information concerning the specimens was written directly on the sheet by Schwägrichen: " $\mathrm{An}$ oectangium aquaticum Hedw. Stirp. III. t. / a. von Hedwig / b. [W...] [Goo...] in [...] 1800 / c. von Host 1799 [... ... $\quad . .$.$] ." The protologue completes the information:$ "Hedw. St. cr. III. p. 29. t. II. Hedwigia aquatica".

All the specimens agree with Cinclidotus aquaticus. Those marked "a" are glued in the center of the sheet in Hedwig's manner. There is a halo around each, the result of the type of glue used. Such a halo is also seen around the specimens on the sheet of $C$. fontinaloides, selected as lectotype by Geissler (1995). The specimen to the left is a male plant, the others are female and bear sporophytes. The small one to the right appears to have been removed from the erect one in the middle; it has at its base a sharp trace which seems to fit with a similar trace on a branch of the erect specimen. They resemble Fig. 1-3 of Table XI in Hedwig (1785-1797), corresponding to Hedwigia aquatica, as indicated in the protologue. The specimens marked "b" and "c" are attached to the sheet only at their bases and lack halos. Those marked " $b$ " are at the upper right and left corners; both are female plants and bear sporophytes. The one marked "c" is at the lower right corner and is a male plant, with several perigonia. Both "b" and "c" were added by Schwägrichen to the Hedwig's sheet and because of the dates 1800 and 1799 given by Schwägrichen on the sheet one can conclude that Hedwig did not study them. So, the only Hedwig's specimens on the sheet are those marked "a" (as written by Schwägrichen) and they are illustrated in Hedwig (1785-1797); as the small one to the right and the erect one in the middle are the same specimen, they are both herein selected as lectotype.

\section{ACKNOWLEDGEMENTS}

I thank Dr. Michelle Price, Curator of Bryophytes of G, for kindly allowing me to study Hedwig's specimens. I am grateful to Drs. J. Muñoz and M. J. Cano for their valuable help with the manuscript and bibliographic assistance. Dr. R. Pursell is especially acknowledged for his comments on the manuscript and for improving the English text. This work was carried out with financial support from MCYT of Spain, Projects BOS2000-0296-CO302 and REN2003-00766/GLO. 
Bridel, S. E. 1803. Muscologia Recentiorum 2(3): 131. Gothae, Parisiis.

Crum, H. A. \& Anderson, L. E. 1981. Bartramia. Pp. 637-640 in: Crum, H. A. \& Anderson, L. E. (eds.), Mosses of Eastern North America, vol 1. Columbia Univ. Press, New York.

Florschütz, P. A. 2002. Introduction to Hedwig's "Species Muscorum”, pp. V-XXII. 2nd Indian Reprint. Bishen Singh Mahendra Pal Singh, Dehra Dun.

Fransén, S. 2004. A taxonomic revision of Bartramia Hedw. section Bartramia. Lindbergia 29: 113-122.

Geissler, P. 1995. Cinclidotus P. Beauv. Taxon 44: 614.

Geissler, P. 2000. The Hedwig herbarium and its importance for the nomenclature of mosses. Nova Hedwigia 70: $15-23$.

Geissler, P. \& Frahm, J.-P. 1995. Lectotypification of Barbula ruralis Hedw. (Tortula ruralis (Hedw.) Gärtn., Meyer et Schreb.). Cryptogamie, Bryol. Lichénol. 16: 157-164.

Hedenäs, L. \& Geissler, P. 1999. Lectotypification of Hedwig names: holarctic pleurocarpous mosses. Candollea 54: 417-432.

Hedwig, J. 1785-1797. Descriptio et adumbratio microscopico-analytica muscorum frondosorum..., 4 vols. Müller, Gleditsch, Lipsiae.

Hedwig, J. 1801. Species Muscorum Frondosorum. Sumtu Joannis Ambrosii Barth, Lipsiae.

Huhtinen, S. 1994. Anyone for oligotypes? Taxon 43: 441-443.

Koponen, T. 1979. Miscellaneous notes on Mniaceae (Bryophyta). IV. Typification of Hedwig's Species of Mniaceae. Ann. Bot. Fennici 16: 7-89.

Pursell, R. A. 1986. Typification of Hedwig's Species of Fissidens. Bryologist 89: 35-41.

Schwägrichen, F. 1816. Species Muscorum Frondosorum, Suppl. I. Barth, Lipsiae.

Smith, A. J. E. 2004. The Moss Flora of Britain and Ireland, ed. 2, pp. 640-644. Cambridge Univ. Press, Cambridge.

$\mathbf{w}^{3}$.MOST 2005. The Moss Data Base at the Missouri Botanical Garden. Available at http://www.mobot.org/MOBOT/ tropicos/most/iom.shtml

$\mathbf{w}^{3}$.ville-ge.ch/cjb 2005. Hed wig Types Catalogue. Le Serveur des Conservatoire et Jardin Botaniques de la Ville de Genève. 